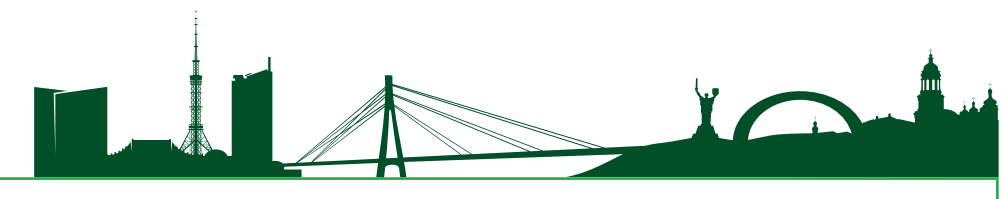

АВТОРИ

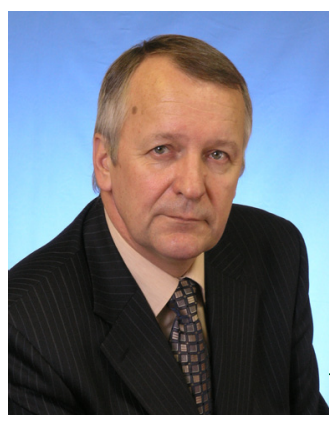

ТАРАСЮК В.Г.

Канд. техн. наук, заступник директора ДП «Державний науково-дослідний інститут будівельних конструкцій» 3 наукової та нормативнометодичної роботи

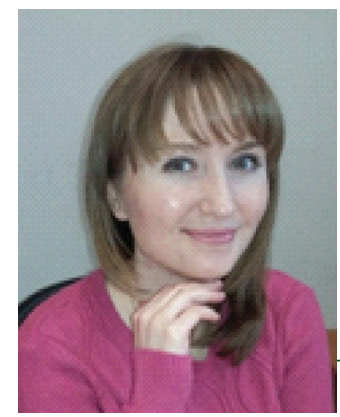

БЕАОКОНЬ О.А.

Канд. техн. наук, завідувач віддіку ДП «Державний науково-дослідний інститут будівельних конструкцій»

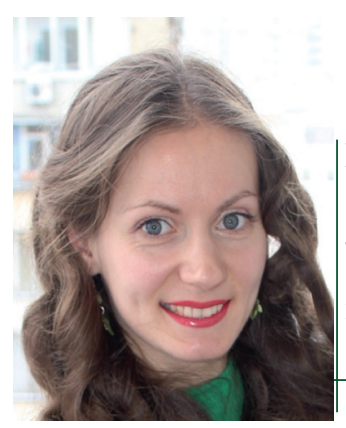

ШЕВЧЕНКО А.M.

Інженер

ДП «Державний

науково-дослідний

інститут будівельних

конструкцій»

\title{
ДІЯАЬНІСТЬ ТЕХНІЧНИХ КОМІТЕТІВ СТАНДАРТИЗАЦІЇ У СФЕРІ БУДІВНИЦТВА НА СУЧАСНОМУ ЕТАПІ
}

УДК 69:006.44

\section{АНОТАЦІЯ}

у статті наведено питання щодо діяльності технічних комітетів стандартизацй у сфері будівництва на сучасноsy emani.

The article describes issues on activity of technical committees on standartization in construction sector at present.

\section{КЛЮЧОВІ СЛОВА}

технічний комітет стандартизації, національний орган стандартизації, положення про технічний комітет стандартизації,секретаріаттехнічних комітетів стандартизації
На сьогодні діяльність технічних комітетів стандартизації в сфері будівництва (далі - технічні комітети) знаходиться на стадії реформування, що в свою чергу створює певні проблеми.

Створення технічних комітетів було розпочато ще у 2008 році з метою удосконалення національної стандартизації у галузі будівництва і промисловості будівельних матеріалів та затверджено наказами Міністерства регіонального розвитку, будівництва та житлово-комунального господарства України (далі - Мінрегіон України) і на сьогодні в сфері будівництва їх налічують близько 20.

Так, діяльність технічних комітетів в сфері будівництва визначена їх структурою, а саме 


\section{W1 1 Nadu}

закріпленими за ними об'єктами стандартизації (кодами УКНд за класами 91 «Будівельні матеріали та будівництво» і 93 «Цивільне будівництво») відповідно до ДК 004 [1] і присвячена питанням світлопрозорих конструкцій, металобудівництва, енергоефективності будівель і споруд, будівельних конструкцій, захисту будівель і споруд, будівельних виробів і матеріалів, інженерних мереж та споруд, автомобільних доріг і транспортних споруд, інженерних вишукувань у будівництві, будівельних технологій, промислового будівництва, ціноутворення та кошторисного нормування у будівництві, житлового будівництва, систем техногенної і пожежної безпеки будівель і споруд, цивільпроекту, технічних аспектів стандартизації у будівництві та промисловості будівельних матеріалів.

Відповідно до Типового положення про технічний комітет стандартизації, затвердженим наказом Держстандарту України від 20.05.2002 № 298 і зареєстрованим в Мін'юсті України 11.07.2002 за № 578/6866, технічні комітети функціонують на підставі затвердженого Положення про технічний комітет в рамках визначеної структури і сфери діяльності згідно з ДК 004 [1]. Технічні комітети створено при відповідних організаціях, що виконують функції їх секретаріатів. До складу технічних комітетів входять відповідні підкомітети, що також працюють відповідно до визначеної сфери діяльності згідно з ДК 004.

На сьогодні статтею 8 Закону України від 5 червня 2014 року № 1315-VII «Про стандартизацію» (далі - Закон України «Про стандартизацію» [2]) визначено, що національний орган стандартизації є суб'єктом стандартизації і виконує роботу стосовно прийняття рішень щодо створення та припинення діяльності технічних комітетів, визначення сфери їх діяльності, координації діяльності технічних комітетів, а також організації та координації діяльності щодо розроблення, прийняття, перевірки, перегляду, скасування та відновлення дії національних стандартів, кодексів усталеної практики та змін до них.

Розпорядженням Кабінету Міністрів України від 26.11.2014 № 1163-р. «Про визначення державного підприємства, яке виконує функції національного органу стандартизації» [3] визначено, що функції національного органу стандартизації (далі - НОС) виконує Державне підприємство "Український науково-дослідний і навчальний центр проблем стандартизації, сертифікації та якості” (далі - ДП “УкрНДНЦ”). В своїй діяльності ДП “УкрНдНЦ” підпорядкований Міністерству економічного розвитку і торгівлі України (далі - Мінекономрозвитку України).

Законом України «Про стандартизацію» визначено, що національний орган стандартизації - орган стандартизації, визнаний на національному рівні, що має право бути національним членом відповідних міжнародних та регіональних організацій стандартизації.

3 03.07.2016 року Мінрегіон України зупинив діяльність у сфері національної стандартизації і НОС почав виконувати функції із розроблення, затвердження, перегляду, внесення змін і скасування національних стандартів і кодексів усталеної практики в сфері будівництва, містобудування та архітектури за класами 91 і 93 згідно з ДК 004.

Таким чином, на сьогодні відбувся перехід технічних комітетів у сфері будівництва за класами 91 і 93 згідно з ДК 004 з Мінрегіону України до НОС, що в свою чергу призвело до процесу реформування вже створених технічних комітетів.

3 метою визначення ефективності та доцільності діяльності технічних комітетів, відповідно до статті 11 Закону України "Про стандартизацію" та відповідно до [4] щодо процедури створення, діяльності та припинення діяльності технічних комітетів стандартизації, НОС аналізує діяльність технічних комітетів.

Тобто, в обмежені терміни НОС виконав роботу щодо перегляду, прийняття та оприлюднення рішень щодо затвердження оновлених Положень про технічні комітети в сфері будівництва, їх структури або про припинення їх діяльності.

Також до повноважень НОС належить:

- прийняття, скасування та відновлення дії національних стандартів, кодексів усталеної практики та змін до них;

- вжиття заходів щодо гармонізації національних стандартів та кодексів усталеної практики 3 відповідними міжнародними, регіональними стандартами та кодексами усталеної практики;

- розроблення за погодженням 3 центральним органом виконавчої влади, що реалізує державну політику у сфері стандартизації (ДП «УкрНДНЦ»), національних стандартів та змін до них щодо:

- процедур розроблення, прийняття, перевірки, перегляду, скасування та відновлення дії національних стандартів, кодексів усталеної практики та змін до них;

- критеріїв, форми і процедур розгляду пропозицій щодо проведення робіт з національної стандартизації;

- процедур створення, діяльності та припинення діяльності технічних комітетів стандартизації;

- забезпечення відповідності національних стандартів та кодексів усталеної практики законодавству;

- забезпечення адаптації національних стандартів та кодексів усталеної практики до сучасних досягнень науки і техніки;

- підготовка та затвердження програми робіт з національної стандартизації;

- участь у підготовці міжнародних, регіональ- 


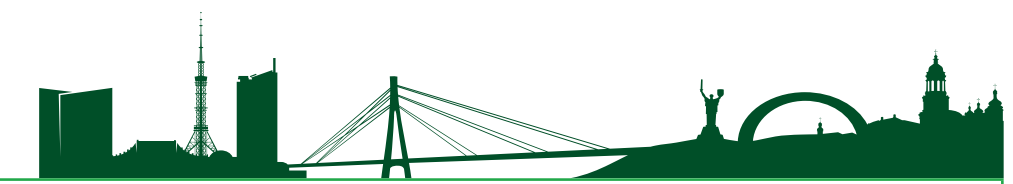

них стандартів та кодексів усталеної практики, що розробляються відповідними міжнародними та регіональними організаціями стандартизації, членом яких є НОС, чи 3 якими він співпрацює, згідно з положеннями таких організацій або відповідними договорами, а також забезпечення врахування інтересів України під час провадження зазначеної діяльності;

- забезпечення та сприяння співробітництву у сфері стандартизації між виробниками, постачальниками, споживачами продукції та відповідними державними органами;

- заохочення суб'єктів малого і середнього підприємництва до участі в розробленні національних стандартів та кодексів усталеної практики, забезпечення доступу зазначених суб'єктів до текстів таких документів;

- підготовка щорічного звіту про свою діяльність, внесення його після схвалення керівною радою на розгляд до центрального органу виконавчої влади, що забезпечує формування державної політики у сфері стандартизації (Мінекономрозвитку України), та оприлюднення на офіційному веб-сайті не пізніше п'яти робочих днів з дня схвалення цього звіту керівною радою, але не пізніше 1 квітня наступного за звітним року.

Також важливо відмітити, що одним із стратегічних завдань НОС на 2016 рік було передбачено налагодження ефективної взаємодії з технічними комітетами із застосуванням сучасних технологій та перехід до побудови технічних комітетів за «дзеркальним принципом» міжнародних та/або регіональних (європейських) технічних комітетів стандартизації.

Так, створення так званого “дзеркального" технічного комітету відповідно до сфери діяльності та об'єктів стандартизації технічних комітетів міжнародних та/або регіональних організацій із стандартизації дозволить не лише здійснювати гармонізацію системи технічних комітетів 3 міжнародними та регіональними, а й забезпечить ефективне впровадження міжнародного досвіду і прогресивних напрацювань на національному рівні.

Активна співпраця технічного комітету із “дзеркальним” міжнародним та/або регіональним технічним комітетом надасть йому низку переваг, зокрема:

- сприятиме економії ресурсів на розроблення стандартів, якщо у певній галузі проводяться роботи на міжнародному та/або регіональному рівнях;

- надаватиме можливість вносити пропозиції та зауваження до проектів міжнародних та/ або регіональних стандартів, що відповідають національним інтересам;

- надаватиме можливість просувати розробле- ні національні стандарти на міжнародний та/або регіональний рівні з подальшим наданням їм статусу міжнародних та/або регіональних;

- дозволить вчасно поінформувати вітчизняних виробників-експортерів про майбутні вимоги міжнародного та/або регіонального стандарту.

Aле на сьогодні здійснити процес реформування вже створених в межах потреби на національному рівні технічних комітетів за «дзеркальним принципом» міжнародних та/або регіональних (європейських) технічних комітетів стандартизації досить складно і не так просто, оскільки побудова міжнародних та/або регіональних (європейських) технічних комітетів стандартизації значно відрізняється від побудови та структури вже створених технічних комітетів.

Таким чином, на сьогодні вирішення питань, що пов’язані 3 національною стандартизацією через технічні комітети в сфері будівництва за класами 91 і 93, напряму залежить від рішень, які приймаються Мінекономрозвитку України через HOC.

Також слід зазначити, що відповідно до [4] технічні комітети в сфері будівництва вже мають звітувати перед НОС та надавати щорічні звіти щодо своєї діяльності.

Зважаючи на вищевикладене, визначаємо, що на сучасному етапі відбувся процес реформування вже створених Мінрегіоном України технічних комітетів стандартизації в сфері будівництва за класами 91 і 93 шляхом затвердження НОС оновлених Положень про технічні комітети, їх структури та об'єкти стандартизації.

Також важливо відмітити, що відповідно до статті 28 Закону України «Про стандартизацію» роботи із стандартизації фінансуються їх замовниками. I джерелами фінансування є: кошти Державного бюджету України; кошти, що передбачені на виконання програм і проектів; власні та залучені кошти суб'єктів господарювання; інші не заборонені законодавством джерела фінансування.

Відповідно до статті 29 Закону України «Про стандартизацію» замовниками послуг з виконання робіт 3 національної стандартизації за рахунок коштів Державного бюджету України є центральні органи виконавчої влади, а єдиним надавачем таких послуг - національний орган стандартизації. Але, на жаль, на сьогодні, фінансування робіт із стандартизації в сфері будівництва не забезпечується ні Мінекономрозвитку України як центральним органом виконавчої влади, що забезпечує формування державної політики у сфері стандартизації, ні Мінрегіоном України як центральним органом виконавчої влади, що забезпечує формування державної політики у будівельній сфері. I тому питання, що пов'язані із фі- 


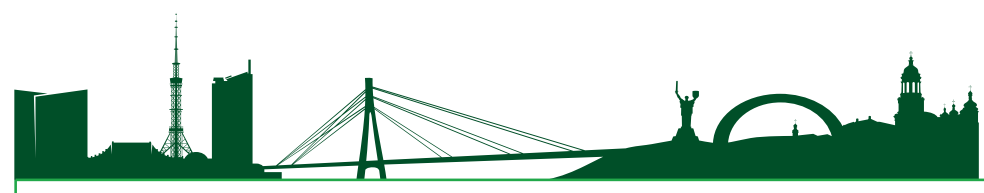

нансуванням робіт із стандартизації в сфері будівництва, має, перш за все, бути урегульоване на рівні держави.

I як показує досвід, єдиними замовниками робіт із стандартизації, на сьогодні є суб'єкти господарювання (виробники продукції), такі, як Асоціація виробників цементу України, Асоціація «Український центр сталевого будівництва», Асоціація «Виробники пінопласту» України, Інтернешнл Рісорсіс Груп, ТОВ «Сен-Гобен Будівельна Продукція Україна», ТОВ «Завод «ТехноНИКО人ь», ЗАТ Парок Аитва, ТОВ з іноземними інвестиціями «Роквул Україна», Українська асоціація «Виробники систем зовнішньої фасадної теплоізоляції», ТОВ «Века Україна», ТОВ «Міропласт» і тіснаспівпраця з останніми шляхом розроблення на їх замовлення національних нормативних документів свідчить про те, що і у нас на Україні виробники продукції переходять на Европейські методи створення нормативних документів.

\section{ЛITEPATУРA}

1. Український класифікатор нормативних документів (ICS:2005, MOD): ДК 004:2008. - [Чинний від 2009-04-01]. - Держспоживстандарт України: Київ, 2009. - VI, 97 с. (Національний класифікатор України).

2. Закон України від 5 червня 2014 року № 1315-VII «Про стандартизацію» // Офіційний вісник України від 15.07.2014. 2014. - № 54. - С. 32-49.

3. Розпорядження Кабінету Міністрів України від 26 листопада 2014 року № 1163-p. «Про визначення державного підприємства, яке виконуе функції національного органу стандартизації» // Офіційний вісник України від 12.12.2014. - 2014. - № 97. C. 160-161.

4. Національна стандартизація. Процедури створення, діяльності та припинення діяльності технічних комітетів стандартизації: ДСТУ 1.14:2015. - [Чинний від 201604-01]. - ДП «УкрНДНЦ»: Київ, 2016. - IV, 42 с. - (Національний стандарт України).

\section{REFERENCES}

1. Ukrainskyi klasyfikator normatyvnykh dokumentiv (ICS:2005, MOD) [Ukrainian classifier of normative documents (ICS:2005, MOD)]. (2009). DK 004:2008 from 01t April 2009. Kyiv: Derzhspozhyvstandart Ukrainy [in Ukrainian].
2. Zakon Ukrainy vid 5 chervnia 2014 r. № 1315-VII «Pro standartyzatsiiu» [Law of Ukraine of June 5, 2014 № 1315-VII «On standardization»]. (2014, 15 July). Ofitsiinyi visnyk Ukrainy - Ofitsiyny News of Ukraine [in Ukrainian].

3. Rozporiadzhennia Kabinetu Ministriv Ukrainy vid 26 lystopada 2014 roku № 1163-r. «Pro vyznachennia derzhavnoho pidpryiemstva, yake vykonuie funktsii natsionalnoho orhanu standartyzatsii» [Order of the Council of Ministers of Ukraine of November 26, 2014 № 1163-p. «Onassignment of the stateenter priseto operateasa national standardization body»]. (2014, 12 Desember). Ofitsiinyi visnyk Ukrainy - Ofitsiyny News of Ukraine [in Ukrainian].

4. Natsionalna standartyzatsiia. Protsedury stvorennia, diyalnosti ta prypynennia diyalnosti tekhnichnykh komitetiv standartyzatsii [National standardization. The procedures of the establishment, operation and termination of the technical committees on standardization]. (2016). DSTU 1.14:2015 from 01t April 2016. Kyiv: National Standard of Ukraine [in Ukrainian]. 